\title{
PEMANFAATAN LIMBAH BOTOL PLASTIK DAN KACA MENJADI PRODUK KREATIF
}

\author{
Supiatun \\ Program Studi Pendidikan Akuntansi Universitas PGRI Palembang \\ supiatunnazar@gmail.com \\ Miftahul Jannah \\ Program Studi Pendidikan Guru Sekolah Dasar FKIP Universitas PGRI Palembang \\ miftauljana79@gmail.com \\ Ela Nindriyani \\ Program Studi Pendidikan Akuntansi Universitas PGRI Palembang \\ ellanindy05@gmail.com \\ Neta Dian Lestari \\ Program Studi Pendidikan Akuntansi Universitas PGRI Palembang \\ neta_obyta@yahoo.com
}

Masuk : 21-11-2020, revisi : 08-01-2021 diterima untuk diterbitkan : 18-01-2021

\begin{abstract}
The problem of waste is a common problem in the world, in the era of the Industrial Revolution 4.0, ready-to-eat food and beverage products resulted in piles of waste which resulted in environmental pollution. Waste that can damage the environment is waste that cannot be decomposed by nature. As a form of saving the earth to reduce the waste of plastic bottles and glass bottles, the younger generation should be able to use them such as pencil boxes, plastic flower vases, chairs, multipurpose storage places and bross. Meanwhile, waste glass bottles can be made into products such as miniatures, flower pots and home decorations.
\end{abstract}

Abstrak: Permasalahan sampah menjadi masalah bersama didunia, pada era Revolusi Industri 4.0, produk makanan dan minuman kemasan siap saji mengakibatkan timbunan sampah yang mengakibatkan pencemaran lingkungan. Sampah yang dapat merusak lingkungan adalah sampah yang tidak dapat terurai oleh alam. Sebagai bentuk penyelamatan bumi mengurangi limbah botol plastik dan botol kaca, sebagai generasi muda harus dapat memanfaatkan seperti kotak pensil, vas bunga bunga dari plastik, kursi, tempat penyimpanan serbaga guna dan bross. Sedangkan limbah botol kaca dapat dibuat produk seperti miniatur, pot bunga dan hiasan rumah.

Kata Kunci: Pemanfaatan, Limbah, Plastik, Kaca

\section{PENDAHULUAN}

Permasalahan sampah menjadi masalah bersama di dunia. Pada era Revolusi Industri 4.0, produk makanan dan minuman kemasan siap saji mengakibatkan timbunan sampah yang mengakibatkan pencemaran. lingkungan. Sebagai generasi milenial yang bukan hanya sekedar memahani ilmu pengetahuan di era disrupsi, namun bagai mana seorang pemuda dapat menjaga kelestarian alam dan lingkungan sekitar sebagai warisan generasi berikutnya. Jangan sampai alam ini rusak di era disrupsi sehingga anak cucu penerus tidak dapat menikmati keindahan alam dan tidak dapat memanfaatkan sumbernya alam, dikarenakan kerusakan ekosistem di sebabkan masalah Sampah atau Limbah. Sampah yang dapat merusak lingkungan adalah sampah yang tidak dapat terurai oleh alam. Menurut Indonesia Solid Waste Association (InSWA) dalam Hutauruk, T.R (2019:1-2), produk sampah plastik Indonesia sekitar 5,4 juta 
ton per tahun. Dalam pemberitahuan kompas.com Tanggal 19 Agustus 2018, mengutip pernyataan Menteri Kelatutan dan Perikanan Republik Indonesia, Susi Pudjiastuti, bahwa Indonesia penyumbang sampah plastik terbesar kedua di dunia.

Menurut DLHK kota Palembang, Faizal AR, masih banyak sampah yang belum terolah dan berakhir ditempat pembuangan. Setiap hari, penduduk yang ada di kota Palembang sekitar 1,8 juta jiwa, dimana produksi sampahnya sekitar 1.300 ton per harinya. (https://infopublik.id/read/279156/dlhk-palembang-butuh-penambahan-500-petugas-

kebersihan.html). Menurut Lestari, N.D (2018:14), rencana pemanfaatan limbah rumah tangga untuk membantu mengurangi banyaknya limbah dan kemudian dijadikan barang kerajinan yang berseni dan bermanfaat. Dengan berkreasi dari limbah botol plastik dan botol kaca, generasi melenial dengan kemampuannya dalam mengakses teknologi, dengan mudah dapat mengkombinasikan dan mengkreatifitaskan limbah tersebut menjadi produk yang bernilai jual ekonomis maupun bernilai jual tinggi. Botol plastik dapat dikreasikan menjadi barang yang bermanfaat seperti kotak pensil, vas bunga bunga dari plastik, kursi, tempat penyimpanan serbaga guna dan bross. Sedangkan limbah botol kaca dapat dibuat produk seperti miniatur, pot bunga dan hiasan rumah. Dengan kreasi dan kreatifitas dari limbah tersebut dapat menjadikan peluang usaha dan menciptakan wirausaha baru dikalangan gene rasi milineal melalui pemasaran sistem online dan langsung.

\section{TELAAH KEPUSTAKAAN}

Limbah merupakan sesuatu yang dianggap tidak berguna dan sisa buangan dari kegiatan industri dan produksi yang tidak memiliki nilai ekonomis. Menurut Indonesia Environment Energy Centre Pengelompokan Limbah, berdasarkan wujudnya dapat dibagi menjadi empat, yaitu limbah cair, limbah padat, limbah gas, dan limbah suara.

Neta \& Toyib (2017:230) menyatakan untuk mengurangi limbah plastik dapat dijadikan sebagai kerajinan tangan atau kreativitas mahasiswa dan limbah plastik dapat berkurang sebnayak $10 \%$. Pemanfaatan limbah botol plastik dan kaca menjadi produk kreatif dapat menghasilkan berbagai produk menghasilkan produk kreatif dan bernilai jual tinggi. Produk kreatif yang memiliki nilai jual tentunya akan dilakukan pemasaran untuk masyarakat luas tahu mengenai produk yang dijual. Menurut Sudaryono (2016:37), pemasaran adalah orang- orang ataupun organisasi yang mempunyai kebutuhan atau produk yang dipasarkan dan mereka itu memiliki daya beli yang cukup guna memenuhi kebutuhan mereka.

Strategi pemasaran dilakukan secara Offline dan Online, strategi pemasaran offline meliputi distribusi flyer atau selebaran. Strategi pemasaran online pemasaran internet adalah proses penyusunan komunikasi terpadu yang bertujuan untuk memberikan informasi menganai produk barang atau jasa dalam kaitannya untuk memuaskan kebutuhan dan keinginan mausia melalui media internet. Menurut Harman (2017:300), pemasaran melalui internet membuat pelanggan mampu memilih produk yang dinginkan tanpa harus membuang waktu untuk pergi ke tempat dia membutuhkan barang atau produk sesuai kebutuhan. Menurut Gumilang \& Hidayatullah (2018:35), Bisnis Online adalah usaha komersial dalam dunia perdagangan yang dilakukan di dalam jaringan "adapun jaringan yang dimaksud adalah jaringan internet".

\section{METODOLOGI PENELITIAN}

Secara umum hasil dari penelitian kreativitas mahasiswa yaitu pemanfaatan limbah botol plastik dan kaca menjadi produk kreatif antara lain:

\section{Persiapan}

Tahap persiapan tim pengusul mengadakan rapat untuk merealisasikan kegiatan proses pembuatan konsep video dilaksanakan dirumah masing-masing. Secara kreatif dan inovatif. Menurut Ngalimun (203:44), kreativitas didefinisikan sebagai kemampuan untuk menciptakan sesuatu yang baru. Setelah mengadakan rapat sebagai salah satu proses persiapan dilanjutkan dengan pembuatan produk kreatif. 


\section{Alat dan Bahan}

Adapun alat dan bahan serta langkah-langkah yang digunakan dalam pembuatan produk kreatif:

a. Kotak pensil

\section{Tabel 1}

\section{Alat dan Bahan}

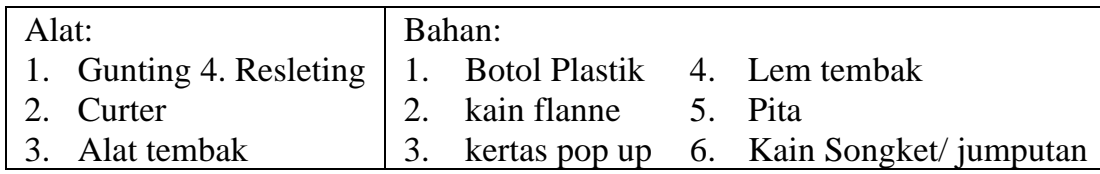

Langkah- langkah kotak pensil:

1) Langkah 1: Memilih botol plastik ukuran sedang.

2) Langkah 2: Potong botol plastik dengan ketinggian yang berbeda. Setelah botol plastik telah terpotong rekatkan kain jumputan/songket. dengan lem tembak dibotol, setelah itu rekatkan resleting pada bagian potongan botol plastik tadi. Bentuk kain flannel seperti kerucut rekatkan dibagian atas botol.

3) Langkah 3: Potong kertas pop up dan rekatkan dibagian bawah botol, diantara kertas pop up dan kain flannel tadi beri pita agar batas antara kertas pop up dan kain flanel tidak terlihat. Lalu bentuk mata, mulut dan tempelkan dibagian badan botol. kotak pensil siap digunakan.

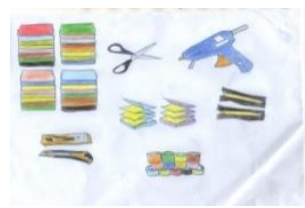



Gambar 1



Produk Kreatif Berupa Kotak Pensil

b. Vas Bunga

Tabel 2 Alat dan Bahan

\begin{tabular}{|c|c|c|}
\hline Alat: & Bahan: & \\
\hline 1. Cutter 4. Spidol & 1. Botol plastik bekas & Cat akrilik \\
\hline 2. Gunting & Karton & Tinta \\
\hline 3. Kuas & 3. Kain Jumputan/ Songket & 6. Lakban \\
\hline
\end{tabular}

Langkah- langkah pembuatan vas bunga dari botol plastik:

1) Langkah 1: Siapkan pola gambar yang akan anda tempatkan pada botol plastik. Misalnya pola/gambar beruang. gambar pola tersebut pada botol plastik lalu potong mengikuti gambar polanya.

2) Langkah 2: Selanjutnya, cat potongan botol plastik, kemudian cat dengan warna putih. cat lagi botol plastik tersebut sesuai dengan karakter pola yang digambar tadi. Gambar mata, hidung, ataupun hidung pada polanya agar tampilannya semakin lucu tampak seperti kartun.

3) Langkah 3: Keringkan sampai catnya agar hasil lebih sempurna, tempelkan kain jumputan/songket dengan menggunakan lem di bagian atas botol, vas bunga dari botol plastik siap digunakan.

c. Vas bunga dari botol kaca

Langkah - langkah pembuatan vas bunga dari botol kaca:

1) Langkah 1: Siapkan botol kaca, lalu tempelkan lakban di bagian badan botol.

2) Langkah 2: Selanjutnya cat seleruh bagian botol kaca, diamkan diempat yang ada sinar matahari untuk hasil yang lebih sempurna, tempelkan kain jumputan/songket pada bagain luar botol.

3) Langkah 3: lepaskan lakban yang ada di badan botol tadi, lalu isi air dan letakkan bunga didalamnya. Maka vas bunga dari botol kaca siap digunakan 

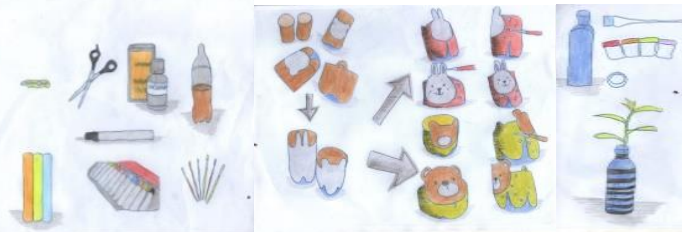

Gambar 2

d. Kursi



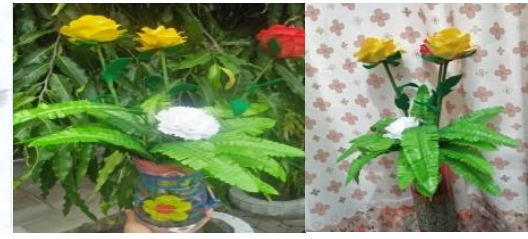

(a)

\section{Produk Kreatif Berupa Vas Bunga (Botol Plastik) \& Vas Bunga (Botol Kaca)}

Tabel 3

\begin{tabular}{|l|lll|}
\multicolumn{4}{c|}{ Alat dan Bahan } \\
\begin{tabular}{|lllll|}
\hline Alat: & Bahan: & \\
1. Gunting & 1. Botol plastik & 5. & Lem \\
2. Jarum & 2. Busa & 6. Benang \\
& & 3. Kain & 7. & Kain jumputan/ songket \\
& 4. Kardus & & \\
\hline
\end{tabular}
\end{tabular}

Langkah- langkah pembuatan kursi dari botol bekas plastik:

1) Langkah 1: kumpulkan botol bekas yang berukuran sama besar, rekatkan semua menjadi satu bagian lakban, sampai berbentuk lingkaran.

2) Langkah 2: Gunakan kardus bekas yang sudah dipotong menjadi lingkaran untuk menjadi alas penutup bagian atas dan bawah bagian botol. Kemudian rekatkan semuanya dengan lakban plastik hingga semua benar- benar terikat rapi.

3) Langkah 3: Bungkus semua bagian dengan menggunakan busa yang empuk, lapisi semua bagian. Setelah semua bagian tertutup, rapikan dengan menjahitnya agar busa tidak lepas. Jahit pada bagian sambungan atas dan bawahnya.

4) Langkah 4: jika busa sudah rapi, tutuplah busa tadi dengan kain jumputan/songket. Setelah semua langkah sudah dilakukan kursi siap digunakan.
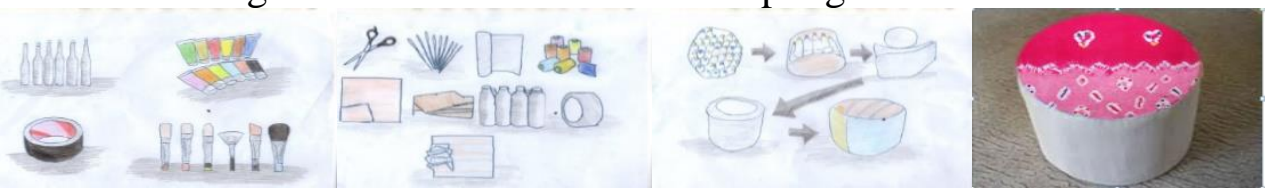

\section{Gambar 3}

e. Tempat penyimpanan serbaguna

\section{Produk Kreatif Berupa Kursi}

\begin{tabular}{l}
\multicolumn{9}{c|}{ Tabel 4 } \\
\begin{tabular}{|l|lll|}
\hline Alat: & Bahan: & \\
1. Gunting dan Bahan \\
\cline { 2 - 4 } & 1. Botol & 4. & Cat \\
& 2. Kain Flannel & 5. & Kain jumputan/songket \\
& 3. Lem tembak & & \\
\hline
\end{tabular}
\end{tabular}

Langkah-langkah pembuatan penyimpanan serba guna sebagai berikut:

1) Langkah 1: Siapkan botol, potong bagian bawah botol sekitaran $5 \mathrm{~cm}$ sampai botol terpotong menjadi dua bagian. Ambil bagian botol yang bagian bawah lalu cat botol tersebut, tunggu sampai kering

2) Langkah 2: Selanjutnya tempelkan kain jumputan/ songket dibagian atas menggunakan lem dan tunggu sampai kering.

3) Langkah 3: Lalu tempelkan satu dengan yang lain dan kotak serba guna siap digunakan.
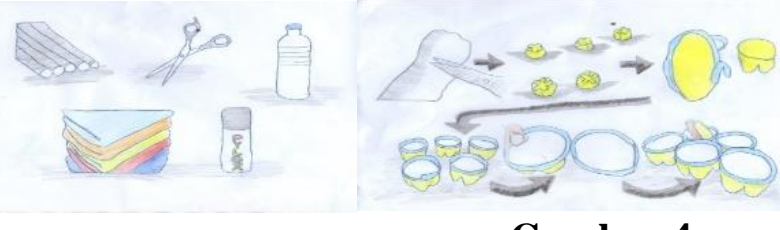

Gambar 4

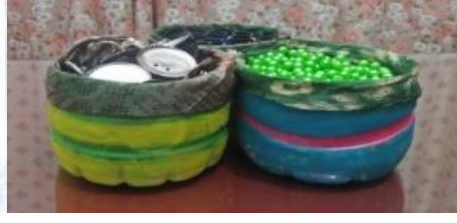

Produk Kreatif Berupa Tempat Penyimpanan Serbaguna 
f. Bross

\section{Tabel 5}

Alat dan Bahan

\begin{tabular}{|l|lll|}
\hline \multicolumn{2}{|l|}{ Alat: } & \multicolumn{3}{l|}{ Bahan: } & \\
1. Gunting 4 peniti & 1. Kain & 4. Manik- manik \\
2. Benang & 2. Lem & 5. & Benang \\
3. Jarum & 3. Kain warna putih & 6. & Kain Jumputan/ songket \\
\hline
\end{tabular}

Cara pembuatan bross dari tutup botol plastik sebagai berikut:

1) Langkah 1: Siapkan alat dan bahan berupa gunting, jarum, benang, tutup botol, lem, manik- manik, peniti, kain jumputan/songket. Buat potongan berbentuk bulat menggunakan kain warna putih dan kardus. Lem dua bulatan tersebut menjadi Satu.

2) Langkah 2: Tempelkan kain perca dengan tutup botol. Lalu jahit kain jumputan/songket yang sudah disatukan dengan tutup botol tersebut sampai berbentuk topi.

3) Langkah 3: Rekatkan kain jumputan/songket yang telah berbentuk bunga yang dikasih manik manik ke bross yang berbentuk topi tadi.

4) Langkah 4: Selanjutnya Rekatkan peniti menggunakan lem. Tunggu sampai kering dan bross siap digunakan.

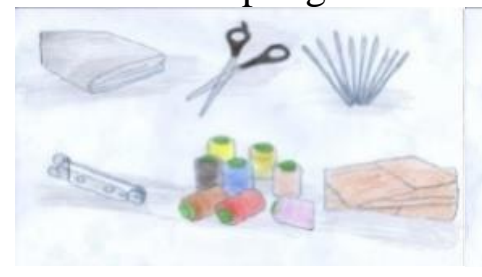

g. Lampu Hias
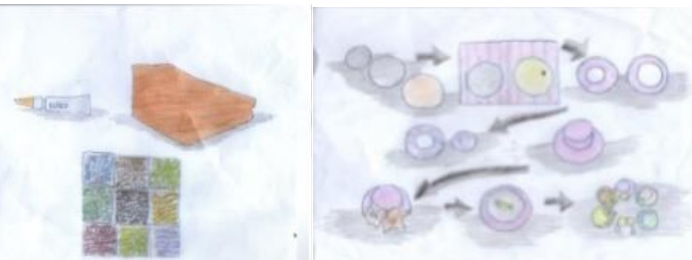

\section{Gambar 3 \\ Produk Kreatif Berupa Bross}

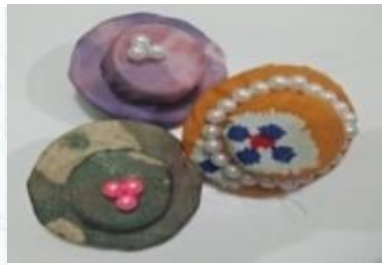

Tabel 6

Alat dan Bahan

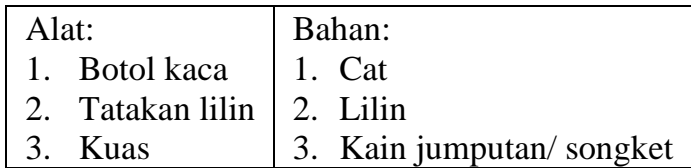

Langkah - langkah pembuatan lampu hias:

1) Langkah 1: bersihkan botol kaca selanjutnya potong bagian bawah botol kaca

2) Lagkah 2: Lukis dan gambarlah botol kaca sesuai bentuk yang diinginkan seperti gambar bunga, abstrak, pepohonan, tapi jangan terlalu agar cahaya yang dihasilkan lampu tidak terhalang dan tunggu sampai kering. Rekatkan kain jumputan/songket pada botol.

3) Langkah 3: nyalakan lilin diatas tempat tataka lilin, selanjutya tutup lilin yang menyala tafdi memakai botol yang sudah dilukis, dan lampu hias siap digunakan

\section{Tahap Pemasaran Produk}

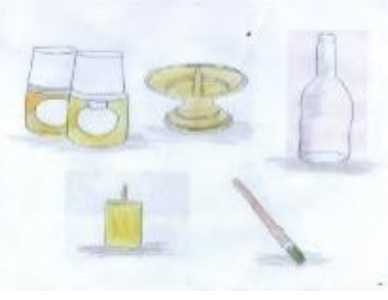

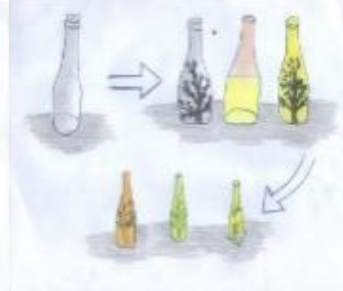

\section{Gambar 6}

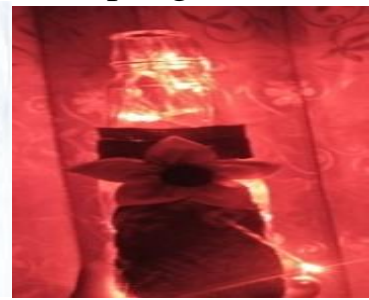

Produk Kreatif Berupa Lampu Hias

Pemasaran dilakukan di aplikasi WhatsAPP, Instagram, Facebok, Shopee, Ojek Online dan kurir. Jika tidak sedang masa pandemi Covid-19, penjualan produk dapat dilakukan pemasaran secara Offline seperti penitipan Produk kreatif di Koperasi Universitas Omi Mart, membuka lapak di tempat rekreasi seperti Kambang Iwak (KI), Benteng Kuto Besak (BKB) dan Jakabaring Sport Centre (JSC). 


\section{Pencapaian Tujuan}

Berhubungan dengan pencapai tujuan dari penelitian program kreativitas mahasiswa ialah adanya video pelaksanaan.

\section{Managemen Usaha (Evaluasi dan Pelaporan)}

Manajemen dilaksanakan dalam pembagian tugas dalam proses pembuatan laporan kemajuan, pembuatan video. Video yang dibuat oleh tim peneliti pemanfaatan limbah botol plastik dan kaca menjadi produk kreatif dijadikan contoh untuk mengolah limbah botol plastik dan kaca menjadi produk yang kreatif, berdaya guna dan bernilai jual.

\section{ANALISA \& PEMBAHASAN}

Hasil yang dicapai berdasarkan luaran program Program Kreativitas MahasiswaKewirausahaan dengan judul "Pemanfaatan Limbah Botol Plastik dan Kaca Menjadi Produk Kreatif" berupa konsep cara memanfaatkan limbah botol plastik dan kaca menjadi produk kreatif, video motivasi. Potensi khusus yaitu produk dari limbah botol plastik dan kaca menjadi produk kreatif yaitu meningkatnya nilai guna botol plastik dan kaca menjadi produk kreatif yang biasanya menjadi sampah yang sulit terurai, meningkatkan minat mahasiswa dan masyarakat untuk berwirausaha, menambah peluang usaha baru dengan memanfaatkan limbah botol kaca dan plastik.

\section{KESIMPULAN}

Kegiatan Penelitian Progran Kreativitas Mahasiswa Pemanfaatan Limbah Botol Plastik dan Kaca membuka peluang usaha bagi mahasiswa dan membantu mengurangi limbah botol plastik dan kaca. Kegiatan Penelitian ini menjadi badan usaha yang mandiri karena memberikan keuntungan. Serta memberikan manfaat bagi penggunanya, terutama menjaga dan melestarikan lingkungan disekitar. Ucapan terima kasih kepada Direktorat Jendral Pembelajaran dan Kemahasiswaan Direktorat Pendidikan Tinggi Kementerian Pendidikan dan Kebudayaan yang telah membiayai pelaksanaan Penelitian Program Kreativitas Mahasiswa Kewirausahaan dan Rektorat Universitas PGRI Palembang karena telah banyak membantu dan memfasilitasi sehingga Penelitian kami dapat berjalan dengan baik dan lancar.

\section{DAFTAR PUSTAKA}

Hutauruk, T. R. (2019). Manajemen Inovasi sebagai solusi kebijakan terhadap persoalan sampah plastik di kota Samarinda. Jurnal Riset Inosa, 1(1).

Lestari, N. D., \& Febrianti, A. (2018, November). Analisis kegiatan program kreativitas mahasiswa kewirausahaan (PKM-K) pemanfaatan limbah rumah tangga (kaleng, kaca, styrofoam, kardus, kulit telur). PROMOSI, 6(2), 14.

Lestari, N. D., \& Toyib, M. (2017, November ). Limbah lingkungan sebagai media pembelajaran untuk menumbuhkan jiwa kewirausahaan mahasiswa Universitas Ogri Palembang. Faktor Jurnal Ilmiah Kependidikan, 4, 227-240.

Ngalimun. (2013). Strategi dan Model Pembelajaran . Yogyakarta: Aswaja.

Nisa, K., Laili, A., Qolbiyatul, S., \& Suyanto, M. (2018). Strategi pemasaran online dan offline. Jurnal Abdikarya : Jurnal Karya Pengabdian Dosen dan Mahasiswa. 1.

Sudaryono. (2016). Manajemen Pemasaran Teori \& Implementasi. Yogyakarta: C.V Andi Offset (penerbit ANDI). 